\title{
Association between IL2RA and juvenile idiopathic arthritis (JIA) disease severity at first presentation to paediatric rheumatology: results from the Childhood Arthritis Prospective Study (CAPS)
}

\author{
KL Hyrich ${ }^{* 1}$, SD Lal ${ }^{1}$, A Hinks ${ }^{1}$, LR Wedderburn ${ }^{2}$, J Gardner-Medwin ${ }^{3}$, \\ H Foster $^{5}$, A Chieng ${ }^{6}$, J Davidson ${ }^{3}$, E Baildam ${ }^{4}$ and W Thomson ${ }^{1}$
}

Address: ${ }^{1}$ University of Manchester, Manchester, UK, ${ }^{2}$ Institute of Child Health, London, UK, ${ }^{3}$ Royal Hospital for Sick Children, Glasgow, UK, ${ }^{4}$ Royal Liverpool Children's Hospital, Liverpool, UK, ${ }^{5}$ University of Newcastle, Newcastle, UK and ${ }^{6}$ Royal Manchester Children's Hospital, Manchester, UK

* Corresponding author

from $15^{\text {th }}$ Paediatric Rheumatology European Society (PreS) Congress

London, UK. 14-17 September 2008

Published: 15 September 2008

Pediatric Rheumatology 2008, 6(Suppl I):PI4 doi:I0.II86/I546-0096-6-SI-PI4

This abstract is available from: http://www.ped-rheum.com/content/6/SI/PI4

(C) 2008 Hyrich et al; licensee BioMed Central Ltd.

\section{Background}

CAPS was designed to study clinical and genetic predictors of JIA outcome. The gene IL2RA has recently emerged as a JIA susceptibility locus. This study investigates the association between SNPs located within the IL2RA region and disease severity at first presentation to rheumatology.

\section{Methods}

Demographic and disease features were collected at first presentation to rheumatology. SNPs(rs2104286, rs41295061, rs11594656) were genotyped on a Sequenom MassARRAY ${ }^{\circledast}$ platform. Logistic regression, adjusted for ILAR subtype, was used to determine the association between genotype and moderate to severe disability(defined as CHAQ score $\geq 0.75$ ).

\section{Results}

185 children with JIA (median age 7.2 years(IQR 3.6, $11.7), 65 \%$ female) were included. Median CHAQ score at presentation was $0.75(\mathrm{IQR} 0.13,1.38)$. There was a trend towards higher disability with increased number of copies of the rare allele of rs2104286 (Table 1) (OR 8.00 $(0.93,68.79), p=0.06)$. An association was also seen between increased disability and homozygosity for the rare allele of rs11594656 (OR $3.37(0.89-12.75), p=$ $0.07)$. There was no association with rs 41295061.

\section{Conclusion}

Children homozygous for the rare allele (rs2104286) a SNP associated with JIA susceptibility, showed a trend towards increased disability. Interestingly, a second SNP in the IL2RA region not previously associated with JIA susceptibility also showed a similar trend. Validation of these results in larger cohorts is required. 
Table I:

\begin{tabular}{|c|c|c|c|c|}
\hline \multirow[t]{2}{*}{ Gene IL2RA } & \multirow[t]{2}{*}{$N(\%)$} & \multirow[t]{2}{*}{ Median CHAQ score(IQR)* } & \multicolumn{2}{|c|}{ OR CHAQ $\geq 0.75(95 \% \mathrm{Cl}), \mathrm{p}$-value } \\
\hline & & & Unadjusted & Adjusted \\
\hline rs2104286 & 185 & & & \\
\hline 11 & $119(64)$ & $0.75(0.13,1.38)$ & Ref & Ref \\
\hline 12 & $58(31)$ & $0.81(0.25,1.38)$ & $1.06(0.56,1.99), p=0.86$ & $1.05(0.54,2.03), p=0.88$ \\
\hline 22 & $8(4)$ & $0.94(0.81,1.38)$ & $6.02(0.72,50.42), P=0.09$ & $8.00(0.93,68.79), p=0.06$ \\
\hline rs|l594656 & 185 & & & \\
\hline II & $100(54)$ & $0.88(0.13,1.44)$ & Ref & Ref \\
\hline 12 & $68(37)$ & $0.63(0.13,1.07)$ & $0.63(0.34,1.18), p=0.15$ & $0.64(0.33,1.21), p=0.17$ \\
\hline 22 & $17(9)$ & $1.38(0.88,1.88)$ & $3.52(0.95,13.02), p=0.06$ & $3.37(0.89,12.75), p=0.07$ \\
\hline
\end{tabular}

Publish with Biomed Central and every scientist can read your work free of charge

"BioMed Central will be the most significant development for disseminating the results of biomedical research in our lifetime. " Sir Paul Nurse, Cancer Research UK

Your research papers will be:

- available free of charge to the entire biomedical community

- peer reviewed and published immediately upon acceptance

- cited in PubMed and archived on PubMed Central

- yours - you keep the copyright 